\title{
PROMOSI E-TICKETING TERHADAP KEPUASAN KONSUMEN YANG BERDAMPAK PADA LOYALITAS PELANGGAN
}

\author{
Lindyastuti Maniek \\ PT Provices Indonesia, Ground Floor Wisma Bakrie 1 \\ Jln. H.R. Rasuna Said Kav B-1, Jakarta 12920 \\ lindyasmanik@gmail.com
}

\begin{abstract}
Internet causes changes in the behavior of individuals and groups within the business done. With the increasing pressures of globalization, companies struggle to find a way to sustain long-term excellence competitiveness. Competitive advantage is the ability to rapidly innovate and absorb innovations from different sources. The development of e-commerce has increased exponentially. E-commerce has been developed as a new market orientation, creating profit opportunities for growth for many industries. One of the industry's growing use of e-commerce systems is air transport industry. Transport industry is one industry that starts using e-ticketing system, replacing the traditional ticketing system. Replacing the traditional paper ticket electronic ticket has now been proven to be an effective commercial practice for organizations operating in the field of transport. E-ticketing can be described as an alternative method of tickets offered by many flight companies which electronic booking records created contain all the information usually printed on a paper ticket. A new revolution in the aviation industry was created by advances in technology. It changes the way airlines in distributing tickets and requires the flight to the next level. Technology given that the electronic ticket is a technology that utilities actually require universal compatibility across airlines.
\end{abstract}

Keywords: internet, e-commerce, e-ticketing

\begin{abstract}
ABSTRAK
Internet menyebabkan perubahan perilaku individu dan kelompok dalam bisnis yang dilakukan. Tekanan globalisasi yang meningkat membuat perusahaan kesulitan untuk mencari jalan untuk mempertahankan keunggulan kompetitif jangka panjang. Keunggulan kompetitif merupakan kemampuan untuk berinovasi terus menerus dan menyerap inovasi dari berbagai sumber. Perkembangan e-commerce telah meningkat secara eksponensial. E-commerce telah dikembangkan sebagai orientasi pasar baru, menciptakan peluang keuntungan untuk pertumbuhan bagi banyak industri. Salah satu industri yang berkembang menggunakan sistem e-commerce yaitu industri transportasi udara. Industri transportasi merupakan salah satu industri yang mulai menggunakan sistem e-ticketing menggantikan sistem pemesanan tiket secara tradisional. Penggantian tiket kertas tradisional dengan tiket elektronik kini telah terbukti menjadi praktik komersial yang efektif untuk organisasi yang beroperasi di bidang transportasi. E-ticketing dapat digambarkan sebagai metode alternatif tiket yang ditawarkan oleh banyak perusahaan penerbangan dengan catatan pemesanan elektronik yang dibuat berisi semua informasi yang biasanya dicetak pada tiket kertas. Salah satu revolusi terbaru dalam industri penerbangan diciptakan dengan kemajuan teknologi. Hal ini mengubah cara maskapai penerbangan dan mendistribusikan tiket, dan teknologi menuntut penerbangan melaju ke tingkat berikutnya. Mengingat, teknologi tiket elektronik tersebut merupakan teknologi yang membutuhkan kesesuaian kegunaan yang universal di seluruh maskapai penerbangan.
\end{abstract}

Kata kunci: internet, e-commerce, tiket elektronik 


\section{PENDAHULUAN}

Beberapa dekade belakangan ini perkembangan yang berkaitan dengan komputer dan media Internet berkembang dengan pesat. Internet menyebabkan perubahan perilaku individu dan kelompok dalam bisnis yang dilakukan. Tekanan globalisasi yang meningkat membuat perusahaan kesulitan mencari jalan untuk mempertahankan keunggulan kompetitif jangka panjang. Keunggulan kompetitif merupakan kemampuan untuk berinovasi dan menyerap inovasi yang cepat dari sumber berbeda (Greve, 2009). Bagi banyak negara, sumber-sumber asing teknologi menjelaskan lebih dari 90\% dari pertumbuhan produktivitas dalam negeri menunjukkan bahwa pola perubahan teknologi global ditentukan terutama oleh teknologi difusi internasional (Keller, 2004).

Perkembangan e-commerce telah meningkat secara eksponensial (Abeyratne, 2005). Ecommerce telah dikembangkan sebagai orientasi pasar baru dan menciptakan peluang keuntungan untuk pertumbuhan bagi banyak industri. Salah satu industri yang berkembang menggunakan sistem e-commerce yaitu industri transportasi udara. Industri transportasi merupakan salah satu industri yang mulai menggunakan sistem e-ticketing. Sistem ini menggantikan sistem pemesanan tiket secara tradisional. Selain itu, e-ticketing menjamin penanganan lebih mudah dari perubahan jadwal, menitmenit terakhir keputusan perjalanan, dan lebih nyaman untuk pelanggan dari risiko yang terkait dengan kehilangan tiket.

Maskapai penerbangan umumnya memiliki model bisnis langsung, seperti pengangkutan penumpang dan barang melalui udara, yang cukup setara di seluruh perusahaan secara global. Maskapai penerbangan juga terbukti menjadi pengadopsi awal informasi teknologi (Buhalis, 2004) yang membuat pemahaman fenomena tertentu lebih relevan. Selain memerlukan informasi teknologi sebagai pendukung bisnis, sistem pemasaran e-ticketing dibutuhkan pula. Ditambah lagi, salah satu manfaat dari keberadaan Internet adalah sebagai media stategi promosi suatu produk.

\section{METODE}

Jenis penelitian yang digunakan merupakan penelitian kausalitas. Penelitian kausalitas, selain mengukur hubungan antara dua variabel atau lebih juga mengukur arah hubungan antara variabel bebas dan terikat, mempertanyakan masalah sebab akibat (Riduwan \& Kuncoro, 2007). Teknik pengambilan sampel (teknik sampling) dilakukan sedemikian rupa sehingga diperoleh sampel yang benar-benar dapat mewakili dan dapat menggambarkan keadaan populasi yang sebenarnya. Hal tersebut dilakukan sebab sampel merupakan bagian dari jumlah dan karakteristik yang dimiliki populasi (Sugiyono, 2011).

Penelitian ini menggunakan beberapa metode analisis. Dalam pelaksanaannya, pengolahan data dilakukan dengan bantuan komputer dengan program SPSS (Statistical Product and Service Solution) versi 16.0. Setelah data dikumpulkan, maka analisis dengan menggunakan Path Analysis dilakukan. Rancangan uji hipotesis yang pertama yaitu melakukan transformasi data ordinal menjadi interval. Mentransformasi data ordinal menjadi interval berguna untuk memenuhi syarat dari analisis parametrik yang datanya setidaknya berskala interval. Teknik transformasi yang paling sederhana dengan menggunakan MSI (Method Of Successive Interval).

Lalu setelah dilakukan transformasi data dilakukan uji validitas dan reliabilitas. Menurut Riduwan (2004), validitas adalah suatu ukuran yang menunjukkan tingkat keandalan atau kesahihan suatu alat ukur-alat ukur dalam penelitian ini adalah kuesioner. Suatu kuesioner dikatakan valid jika setiap butir pertanyaan pada suatu kuesioner mampu untuk mengungkapkan sesuatu yang akan 
diukur oleh kuesioner tersebut. Instrumen reliabel adalah instrumen yang jika digunakan beberapa kali untuk mengukur objek yang sama akan menghasilkan data yang sama (Sugiyono, 2009). Setelah uji validitas dan reliabilitas dilakukan, uji normalitas pada penelitian ini menggunakan alat tes Kolmogorov-Smirnov yang terdapat pada SPSS 16.0 dengan tingkat signifikansi sebesar $0.05 \%$, dilanjutkan dengan uji korelasi. Setelah beberapa uji menggunakan SPSS 16.0 lalu dilakukan pengujian menggunakan path analysis.

\section{HASIL DAN PEMBAHASAN}

Kuesioner disebar dan dibagikan kepada responden penelitian yang berjumlah 100 orang. Hasil kuesioner diketahui dan digolongkan menjadi beberapa karakteristik berdasarkan usia, jenis kelamin, pekerjaan, pendapatan atau uang saku, dan frekuensi pembelian online ticketing. Secara berturut-turut, hasil kuesioner kepada responden ditunjukkan pada Gambar 1 - Gambar 5.

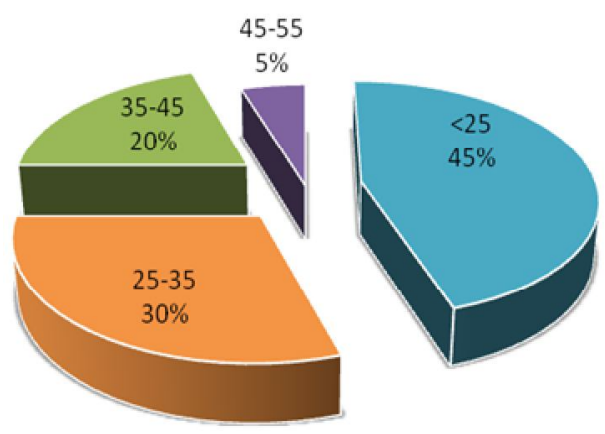

Gambar 1 Profil Responden Berdasarkan Usia

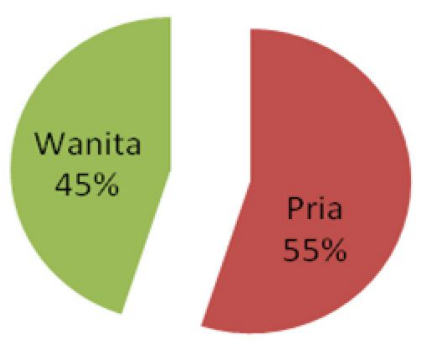

Gambar 2 Profil Responden Berdasarkan Jenis Kelamin

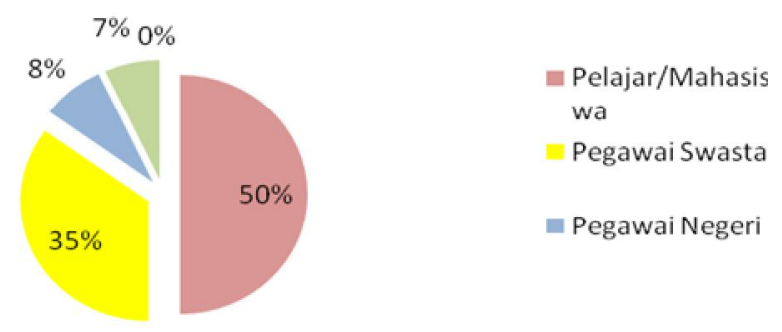

Gambar 3 Profil Responden Berdasarkan Pekerjaan 


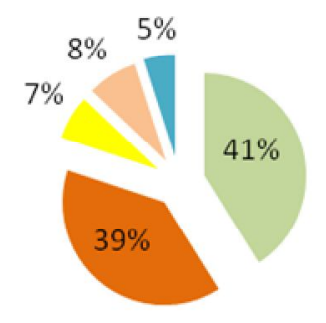

Gambar 4 Profil Responden Berdasarkan Pendapatan atau Uang Saku

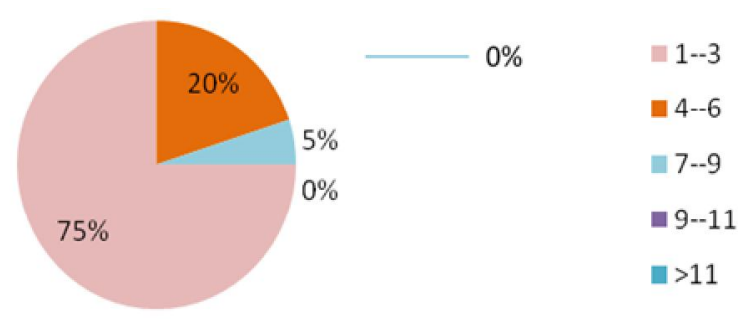

Gambar 5 Profil Responden Berdasarkan Frekuensi Pembelian

Berdasarkan usia, $45 \%$ responden berusia di bawah 25 tahun; $30 \%$ berusia di antara 25-30 tahun; 20\% berusia 35-45 tahun; dan 5\% sisanya berusia 45-55 tahun. Jenis kelamin responden $55 \%$ adalah laki-laki dan $45 \%$ adalah perempuan. Kemudian berdasarkan pekerjaan, $50 \%$ responden adalah pelajar dan mahasiwa, $35 \%$ adalah pegawai swasta, $8 \%$ pegawai negeri. Penghasilan atau uang saku responden, $41 \%$ berpenghasilan di bawah 1.500 .000 rupiah; $39 \%$ berpenghasilan antara $1.500 .000-3.000 .000$ rupiah; $8 \%$ berpenghasilan $4.500 .000-6.000 .000$ rupiah; $7 \%$ berpenghasilan $3.000 .000-4.500 .000$ rupiah; dan 5\% di atas 6 juta rupiah. Pada frekuensi pembelian responden, $3 / 4$ responden (75\%) melakukan 1-3 kali pembelian; 20\% melakukan 4-6 kali pembelian; dan 5\% sisanya 7-9 kali pembelian.

Uji korelasi promosi e-ticketing, kepuasan konsumen, dan loyalitas pelanggan ditunjukkan pada Tabel 1. Sedangkan tabel Anova pengaruh secara simultan variabel-variabel ini ditunjukkan pada Tabel 2.

Tabel 1 Uji Korelasi antara Promosi e-Ticketing dan Kepuasan Konsumen

\begin{tabular}{|c|c|c|c|c|}
\hline \multicolumn{5}{|c|}{ Correlations } \\
\hline & & Promosi ticketing & Kepuasan Konsumen & Loyalitas Pelanggan \\
\hline \multirow[t]{3}{*}{ Promosi ticketing } & Pearson Correlation & 1.000 & $.968^{* *}$ & $.951^{* *}$ \\
\hline & Sig. (2-tailed) & & .000 & .000 \\
\hline & $\mathrm{N}$ & 100.000 & 100 & 100 \\
\hline \multirow[t]{3}{*}{ Kepuasan Konsumen } & Pearson Correlation & $.968^{* * *}$ & 1.000 & $.985^{* *}$ \\
\hline & Sig. (2-tailed) & .000 & & .000 \\
\hline & $\mathrm{N}$ & 100 & 100.000 & 100 \\
\hline \multirow[t]{3}{*}{ Loyalitas Pelanggan } & Pearson Correlation & $.951^{* *}$ & $.985^{* *}$ & 1.000 \\
\hline & Sig. (2-tailed) & .000 & .000 & \\
\hline & $\mathrm{N}$ & 100 & 100 & 100.000 \\
\hline
\end{tabular}


Tabel 2 Pengaruh Secara Simultan

\begin{tabular}{llccccc}
\hline \multicolumn{7}{c}{ ANOVA $^{\mathbf{b}}$} \\
\hline Model & & Sum of Squares & df & Mean Square & F & Sig. \\
\hline 1 & Regression & 15.710 & 2 & 7.855 & 1594.110 & $.000^{\mathrm{a}}$ \\
& Residual & .478 & 97 & .005 & & \\
& Total & 16.188 & 99 & & & \\
\hline
\end{tabular}

Implementasi promosi e-ticketing dari website dan media sosial memiliki pengaruh yang signifikan dan positif terhadap kepuasan konsumen dari layanan promosi e-ticketing PT Kem Travel. Timbulnya pengaruh tersebut disebabkan pengalaman perusahaan yang sudah berdiri sejak 1992 yang dipimpin oleh para profesional yang sudah berkecimpung di bagian travel selama lebih dari 20 tahun. Ditambah lagi, pengalaman konsumen yang sudah lama menggunakan jasa Kem Travel untuk fasilitas dalam pemesanan tiket wisata baik domestik maupun internasional. Selain itu, Kem Travel juga juga melayani layanan haji dan umroh.

Implementasi promosi e-ticketing yang berdampak pada loyalitas pelanggan memiliki pengaruh yang signifikan dan positif terhadap kepuasan konsumen. Promosi e-ticketing yang dilakukan perusahaan dapat menarik minat konsumen untuk menggunakan fasilitas jasa dari Kem Travel. Promosi yang dijalankan perusahaan yang berhasil menarik minat konsumen dapat menimbulkan loyalitas pelanggan. Pelanggan yang loyal, pada akhirnya, akan melakukan pembelian dan menggunakan $e$-ticketing melalui PT Kem Travel secara berulang.

Implementasi kepuasan konsumen memiliki pengaruh yang signifikan terhadap loyalitas pelanggan. Timbulnya pengaruh tersebut dapat disebabkan dari kualitas perusahaan yang berpengalaman cukup lama dan dikelola dengan sumber daya serta tim manajemen yang terorganisasi dan berkompeten di bidangnya. Konsumen selalu beranggapan jika kualitas dari suatu jasa bagus, produk dan jasa bagus pula. Maka dari itu, konsumen akan loyal terhadap layanan Internet ticketing dan terus menggunakannya.

Implementasi promosi e-ticketing terhadap kepuasan konsumen secara simultan berdampak pada loyalitas pelanggan. Jika promosi suatu produk atau jasa baik, jasa dan produk tersebut harus memiliki kualitas yang baik pula. Kualitas yang baik, kemudian, akan menimbulkan loyalitas konsumen. Konsumen akan percaya dengan layanan jasa e-ticketing PT Kem Travel jika perusahaan memberikan pelayanan yang baik. Setelah konsumen puas, maka loyalitas akan muncul dari konsumen.

\section{SIMPULAN}

Berdasarkan analisis hasil pengolahan data, penelitian menyimpulkan bahwa perusahaan harus lebih meningkatkan promosi e-ticketing layanannya sehingga dapat menarik minat konsumen dan meningkatkan loyalitas pelanggan. Selain itu, simpulan yang berkaitan dengan tujuan penelitian dan juga implikasi penelitian adalah sebagai berikut. Pertama, pengaruh promosi e-ticketing dari website dan media sosial signifikan dan positif terhadap kepuasan konsumen dari layanan promosi $e$ ticketing. Promosi yang menarik akan menarik minat dan meningkatkan kepuasan konsumen/pelanggan yang menggunakan jasa Kem Travel. Kedua, promosi e-ticketing berdampak pada loyalitas pelanggan, sehingga memiliki pengaruh yang signifikan dan positif terhadap kepuasan konsumen. Promosi yang berhasil menarik minat konsumen dapat menimbulkan loyalitas pelanggan yang pada akhirnya akan melakukan pembelian dan menggunakan e-ticketing melalui PT Kem 
Travel secara berulang. Ketiga, kepuasan konsumen memiliki pengaruh yang signifikan terhadap loyalitas pelanggan. Konsumen yang puas dengan kualitas jasa akan loyal terhadap layanan Internet ticketing dan terus menggunakannya. Keempat, promosi e-ticketing terhadap kepuasan konsumen secara simultan memiliki dampak pada loyalitas pelanggan. Setelah konsumen puas dengan layanan jasa $e$-ticketing Kem Travel, maka konsumen akan loyal terhadap perusahaan.

\section{Saran}

Berdasarkan hasil penelitian ini, saran penelitian diberikan untuk dua pihak, yaitu bagi perusahaan (PT Kem Travel) dan bagi penelitian selanjutnya. Bagi Kem Travel, pertama, perusahaan sebaiknya lebih berfokus pada promosi e-ticketing yang akan memberikan persepsi atau tanggapan lebih terhadap loyalitas pelanggan e-ticketing Kem Travel. Kedua, perusahaan sebaiknya berfokus pula terhadap loyalitas pelanggan walaupun perusahaan memiliki anggapan konsumen sudah percaya terhadap kinerja kualitas jasa $e$-ticketing. Bagi penelitian selanjutnya, pertama, penelitian selanjutnya dapat mencari tahu promosi yang harus digunakan oleh perusahaan dalam mempromosikan layanan online ticketing Kem Travel. Kedua, penelitian juga dapat mencari tahu cara mengembalikan kepercayaan konsumen yang kecewa terhadap layanan online ticketing Kem Travel.

\section{DAFTAR PUSTAKA}

Abeyratne, R. (2005). Electronic ticketing in air transport-commercial strategies and consequences. Journal of World Trade, 39(6), 1095-1118.

Buhalis, D. (2004). eAirlines: Strategic and Tactical Use of ICTs in the Airlines Industry. Information and Management, 41(7), 805-825.

Greve, H. R. (2009). Bigger and safer: The diffusion of competitive advantage. Strategic Management Journal, 30(1), 1-23.

Keller, W. (2004). International technology diffusion. Journal of Economic Literature. 42(3), 752782 .

Riduwan \& Kuncoro, E. A. (2007). Cara Menggunakan Dan Memaknai Analisis Jalur (Path Analysis). Bandung: Alfabeta.

Riduwan. (2004). Metode dan Teknik Menyusun Tesis. Bandung: Alfabeta.

Sugiyono. (2011). Metode Penelitian Kuantitatif Kualitatif dan R\&D. Bandung: Alfabeta.

Sugiyono. (2009). Metode Penelitian Bisnis. Bandung: Alfabeta. 